Research, part of a Special Feature on Twenty Years of Community Forestry in Cameroon: Opportunities and Challenges for Sustainable Development

\title{
Community forestry and REDD+ in Cameroon: what future?
}

\author{
Florence Bernard ${ }^{1}$ and Peter A. Minang ${ }^{1}$
}

\begin{abstract}
The Cameroonian Readiness Preparation Proposal recognizes community forests (CFs) as one strategy for implementing REDD+ (reducing emissions from deforestation and forest degradation and the role of conservation, sustainable management of forests, and enhancement of forest carbon stocks in developing countries). However, there has been little analysis of the extent to which CFs can help achieve REDD+ objectives in Cameroon. We explore options for REDD+ within CFs, as well as challenges and possible ways forward. Cocoa agroforestry in deforested or highly degraded CFs is currently the most competitive option for implementing REDD+ while delivering ecological, economic, and social cobenefits. Reduced-impact logging and conservation or natural regeneration are technically sound options for emissions reductions within CFs, but are unlikely to compete with other more profitable activities at the current low carbon market prices of approximately USD \$5/tonne of carbon. However, these options could potentially compete under a social cost of carbon estimated at $\$ 43 /$ tonne of carbon. The current CF architecture presents a set of factors that could favor REDD+ implementation, including: good legal and institutional frameworks and practices compatible with REDD+ safeguards, experience and knowledge in related payments for ecosystem services and performance-based finance pilots, and social capital in a community of practice. The CF architecture also features potentially inhibiting factors such as poor governance (notably, elite capture and corruption), unclear carbon rights, and financing challenges. We identify a set of enabling actions for delivery of REDD+ within CFs in Cameroon, which include: clarifying carbon rights; establishing a benefit-sharing mechanism from the national to the local level with clear rules for rewarding emission reductions in CFs; and building monitoring, reporting, and verification infrastructure for REDD+ within CFs. More importantly, adopting an integrated approach in which CFs serve multiple objectives, including ecosystembased adaptation, REDD+, and the original community forestry objectives could enable drawing from both adaptation and mitigation finance, technical support, and provide long-term sustainable development benefits.
\end{abstract}

Key Words: Cameroon; community forests; emission reduction; REDD+

\section{INTRODUCTION}

Since the late 1980 s, community forests (CFs) have emerged in a growing number of developing countries, largely because of failing centralized forest policy. This emergence has occurred in recognition that sustainable forest management can only succeed with the active engagement of local communities and because forests are important to people's livelihoods (Chhatre and Agrawal 2009, Newton et al. 2015). Currently, approximately 18\% of global forest is under community ownership or administration (Rights and Resources Initiative 2015). CF refers to forests in which local communities use and have some degree of formal responsibility and authority for forest management (Arnolds 2001, Ribot 2002, Agrawal et al. 2008). Many authors have argued that CF management has the potential to fulfill the triple objectives of supporting livelihoods, biodiversity conservation, and providing ecological services such as reducing emissions or increasing removals from forests (Agrawal and Angelsen 2009, Skutsch and McCall 2012, Ngendakumana et al. 2013, Newton et al. 2015). In a systematic review, Pelletier et al. (2016) demonstrated that CFs are effective at promoting sustainable forest management and forest conservation $(87.5 \%$ of 33 reviewed case studies), effective at reducing forest degradation $(60 \%$ of 33 case studies), and enhancing carbon stocks (69\% of 33 case studies). For example, CF management in savannah woodlands in East and West Africa achieves sequestration of 1-20 tonnes/ ha of carbon dioxide annually, in addition to reductions in emissions from degradation, which may be on the order of 2 tonnes/ha annually (Skutsch and Solis 2011).

Reducing emissions from deforestation and forest degradation, and the role of conservation, sustainable forest management, and enhancement of forest carbon stocks (REDD+) proposes to deliver multiple outcomes, including emissions reduction, livelihood support, and sustainable forest management, and thus appears largely compatible with CFs (Pelletier et al. 2016). CFs and REDD+ share the objectives of maintaining forest cover by reducing forest conversion to other land uses and maintaining forest integrity by reducing unsustainable resource extraction while securing essential ecosystem services (Newton et al. 2015). Although there are synergies between CFs and REDD+, there are some fundamental difference in their underlying objectives. CFs were developed principally to protect forests and support the subsistence and income-generating extractive activities such as legal small-scale logging and sale of valuable timber or nontimber forest product (NTFP) exploitation by forest-dependent communities (Arnolds 2001). In contrast, REDD+ was developed principally to mitigate climate change. However, for REDD+ to succeed, buy-in, engagement, and meaningful participation of local communities, as well as enhancement of people's livelihoods, have proven to be critical (Agrawal and Angelsen 2009, Tomaselli and Hajjar 2011). Therefore, over the years, CFs became very popular in the global REDD+ discourse compared to other forest-protection approaches such as protected areas that may feature high social costs because of exclusion or restriction of local communities' access and use. The international community has therefore explored possible ways of linking CFs to REDD+ (Agrawal and Angelsen 2009, Skutsch and Solis 2011, Bluffstone 2013, UN-REDD 2013, Pelletier et al. 2016).

Cameroon was the first adopter of community forestry in Central Africa as part of its new decentralized forestry law of 1994 (Egbe 2001, Beauchamp and Ingram 2011). The 1994 forestry law 
brought a radical change, opening the way for community involvement in the sustainable management of their own forests, and correcting their previous exclusion by colonial policy (Brown and Schreckenberg 2001, Movuh 2012). The law was also intended to engage the Ministry of Forestry and Wildlife in active partnerships with civil society in the management of forest resources in an attempt to provide a solution to the previous conflicts over resource exploitation between central government and communities (Amungwa 2011, Movuh 2012). In Cameroon, CFs also aim at providing rural communities with incomegenerating mechanisms for equitable socioeconomic development of their communities, therefore alleviating poverty (Beauchamp and Ingram 2011, Movuh 2012). In > 20 years, > 400 CFs have been registered in almost all regions of the country, with varying activities (Minang et al. 2017). Cameroon has explicitly included CFs in REDD+ planning in recent years. In its readiness preparation proposal, approved by the Forest Carbon Partnership Facility in February 2013, Cameroon states that "development of community forests and green community production enterprises or ecological enterprises" is one of the strategies to implement REDD+ (R-PP Team 2012:51). It also mentions that specific actions may be dedicated to CFs, such as strengthening the management of CFs and identifying conditions in which those forests could guarantee a reduction of deforestation and degradation over time (R-PP Team 2012).

Despite these intentions of deploying CFs as a potential effective and efficient local delivery mechanism for REDD + , little has been done recently in Cameroon to analyze the extent to which CFs can actually deliver on REDD+ objectives or to provide options and approaches for CFs to deliver REDD+. Here, we explore the extent to which CFs in Cameroon can contribute to REDD+ and seek to answer three main questions: (1) What are the options through which CFs can contribute to REDD+ in Cameroon, and how feasible are they? (2) How can the current CF architecture potentially enhance or inhibit REDD+ implementation in Cameroon? (3) How can synergies be enabled between CFs and REDD+ in Cameroon? To do so, we review and analyze publications on REDD+ and community forestry, including primarily peer-reviewed literature, reports, laws, and policy documents, as well as elicit expert knowledge. We first summarize the community forestry landscape and REDD+ background and progress in Cameroon, and then attempt to answer our research questions.

\section{COMMUNITY FORESTRY IN CAMEROON}

\section{Key legal and institutional features of community forests in Cameroon}

Significant progress has been recorded in the legal and institutional landscape for community forestry in Cameroon since the early 1990s (Minang et al. 2017). At the national level, CF development is framed by the Cameroon forestry law 94/01 of 1994 and its decree 95/531 of implementation, which specifies the mandatory stages to establish a $\mathrm{CF}$ and the legal requirements to be observed by communities (Ezzine de Blas et al. 2009). According to the 1994 Cameroonian forest law, CFs refers to “... part of nonpermanent forest estate (not more than 5000 ha) that is the object of an agreement between government and a community in which communities undertake sustainable forest management for a period of 25 years renewable" (MINEF 1998).
As part of the nonpermanent forest estate, the CF therefore provides a legal tool whereby a management agreement is established between a community and the forest administration (Movuh 2012). A manual of the procedures for the attribution and norms for CFs established in 1998 and revised in 2009 describes the procedures and details of the application of the 1994 law (Alemagi 2010). The implementation of a CF involves reserving a community forest area, allocating the forest to the local community after the preparation of a simple management plan (SMP), and sustainably exploiting the forest resources for the benefit of the community on the basis of a management agreement (Minang et al. 2007). The SMP includes a description of the CF natural environment, a forest inventory, calculation of the potential available forest resources, analysis of who has rights regarding the use of forest resources and the benefits arising from activities, the modes of community resource management, and the resulting incomes (Cuny et al. 2007, MINFOF 2009). It is supposed to be a document in which the potentialities of the resources are evaluated; the trade-offs among ecological, economic, and social aspects of management are assessed; and balanced solutions are proposed. However, most SMPs have been oriented to logging activities rather than conservation or other resource valuation activities. One major reason is, because of extremely high management development costs for communities, CFs often delegate the task of developing the SMP to logging companies, which consequently leads to economic and logging aspects receiving more attention than ecological or social aspects. The SMP is developed with a participatory approach, which ensures a high level of ownership by the whole community and provides a safeguard to avoid noncompliance or abuse of the SMP (Klein et al. 2001). The SMP has to be reviewed every five years.

Prior to signing the management agreement between the government and the local community, some requirements must be fulfilled by the communities. These requirements include: (1) constitute a legal entity, i.e., a common initiative group, an economic interest group, an association, or a cooperative, and appoint a community forest manager who will represent the community in negotiations with government in matters of community forestry; (2) delineate and map the intended CF area prior to approval; and (3) present a management plan as part of the conditions for approval. From an institutional perspective, the CF management unit was created in 1999 , followed by the subdirectorate of CFs in the Ministry of Forestry and Wildlife in 2005, which is responsible for coordination of entities implementing $\mathrm{CF}$ s and facilitating the $\mathrm{CF}$ application process and registration. This subdirectorate has played a significant role in anchoring the CF agenda into the bigger forestry strategy of Cameroon as well as in facilitating the process of $\mathrm{CF}$ institutionalization (Minang et al. 2017).

\section{Coverage of community forests in Cameroon}

The total area under CFs is now approximately 1,364,203 ha (WRI 2014), which represents $9 \%$ of the national forest estate. Most CFs in Cameroon are a mix of high-biodiversity natural and secondary forests (Minang et al. 2007). All CFs in Cameroon are part of the nonpermanent forest domain (Table 1), which is forestland that can be given out for different types of activities. They are therefore vulnerable areas exposed or likely to be deforested or degraded to some extent. 
Table 1. Land-use allocation within the national forest estate in Cameroon in 2014. Source: WRI (2014).

\begin{tabular}{llcc}
\hline \hline Allocation type & Allocation subtype & $\begin{array}{c}\text { Number of } \\
\text { allocations }\end{array}$ & $\begin{array}{c}\text { Area (ha) } \\
\text { Proportion of land-use } \\
\text { allocation (\%) }\end{array}$ \\
\hline Permanent forest estate & Forest management unit & 115 & $6,785,464$ \\
& Protected area & 39 & $4,701,138$ \\
& Communal Forests & 41 & $1,638,148$ \\
Nonpermanent forest estate & Community forests & 392 & $1,364,203$ \\
& Sales of standing volume & 84 & 187,539 \\
& Agro-industrial parcels & 74 & 415,937 \\
\hline
\end{tabular}

\section{Key community forest activities in Cameroon}

Most people living in CFs are dependent on the forest to sustain their livelihood. Therefore, several activities are undertaken by local populations to satisfy their daily needs, as well as to generate revenues, e.g., through the generation of $\mathrm{CF}$ enterprises. These activities can include: timber exploitation, i.e., industrial logging through external intermediates or informal small-scale timber harvesting; NTFP collection, e.g., fuelwood, bushmeat, and plants, for subsistence and marketing of those products for medicinal and food uses; agriculture, e.g., subsistence crops including cocoyam, cassava, peanut, plantain, and vegetables, with some households cultivating coffee and cocoa cash crops; agroforestry, e.g., cocoa agroforestry production; and hunting, fishing, charcoal production, and also protection by the forest (Akoa Akoa 2007, Harley 2012). However, inertia has been observed in terms of enterprise development (e.g., for NTFPs and agroforestry), value addition, and sustainable forest management practices (Minang et al. 2019).

\section{REDD+ BACKGROUND AND PROGRESS IN CAMEROON}

REDD + is an international policy and finance mechanism for climate change mitigation that was first proposed at the Conference of the Parties 11 meeting in Montreal in 2005 in which developing countries with tropical forest can elect to engage in the reduction of emissions from forests against an agreed baseline or reference level. Economic incentives, though market and nonmarket mechanisms, are to be provided once the reported emission reduction is verified (White and Minang 2011). The specificity of REDD+ is its incentive system because payments are linked to performance.

The REDD+ readiness requirements outlined in the United Nations Framework Convention on Climate Change Cancun Agreements in 2010 include: (1) a national strategy or action plan, (2) a national forest reference emission level or forest reference level, (3) a robust and transparent national forest monitoring system for the monitoring and reporting of activities, and (4) a system for providing information on internationally agreed safeguards (REDD+ Academy 2015). The REDD+ safeguards are processes or policies designed to prevent the harm of people and the environment while implementing REDD+ activities. Such safeguards include: consistency with national forest programs and international conventions and agreements, transparent and effective national forest governance structures, respect for the knowledge and rights of indigenous peoples and local communities, full and effective participation of relevant stakeholders in REDD+ actions, consistency with the conservation of natural forests and biological diversity, actions to address the risks of reversals, and actions to reduce displacement of emissions (UNFCCC 2011:24-25).

Since 2005, Cameroon has engaged in a process of developing the necessary technical, institutional, and policy competencies for REDD+. In a review of the REDD+ readiness process in Cameroon, Alemagi et al. (2014) found that substantive progress has been made in terms of planning and coordination, institutional development, and piloting REDD+ projects. A conceptual outline for advancing REDD+ social safeguard systems in the country has also been suggested by Fobissie et al. (2012). However, Fobissie et al. (2012) noted prominent constraints such as the absence of a legal framework; inadequate procedures for stakeholder participation; slow progress in the development of a national strategy; lack of equipment with adequate or proper technical and human resources for monitoring, reporting, and verification; and weak financing (Alemagi et al. 2014). In addition, provisions for tenure rights are still vague, and no legal framework for a REDD+ benefit-sharing mechanism currently exists in Cameroon (Alemagi et al. 2014). This situation calls for further review and more efforts to address these issues by the Cameroonian government to implement effective and efficient REDD+.

\section{WHAT OPTIONS FOR REDD+ WITHIN COMMUNITY FORESTRY IN CAMEROON?}

The REDD+ addition of a new value, i.e., carbon sequestration, to the traditional values of CFs (local livelihoods and ecological resilience) produces both synergies and trade-offs. We used literature and expert knowledge to examine the potential of key $\mathrm{CF}$ activities to achieve REDD+ in terms of potential emissions reductions, associated carbon payments, and economic profitability (Table 2). There are three main activities that present significant technical compatibility with REDD+, namely reduced-impact logging (RIL), conservation or natural regeneration, and cocoa agroforestry, but they also present economic and livelihood trade-offs that are important to understand for REDD+ decision making at the community level. Obviously, timber exploitation, despite being economically profitable for communities, is a practice that is not compatible with any of the REDD+ objectives. There is little evidence on how NTFP exploitation affects carbon stocks, but NTFP extraction could potentially have positive economic and social impacts for communities as well as minimized ecological effects compared to timber logging. We further examine each CF activity with respect to REDD+ objectives. 
Table 2. Potential of key community forestry activities to achieve REDD+ targets and their impact appraisal in terms of emissions reductions and ecological, economic, and social aspects.

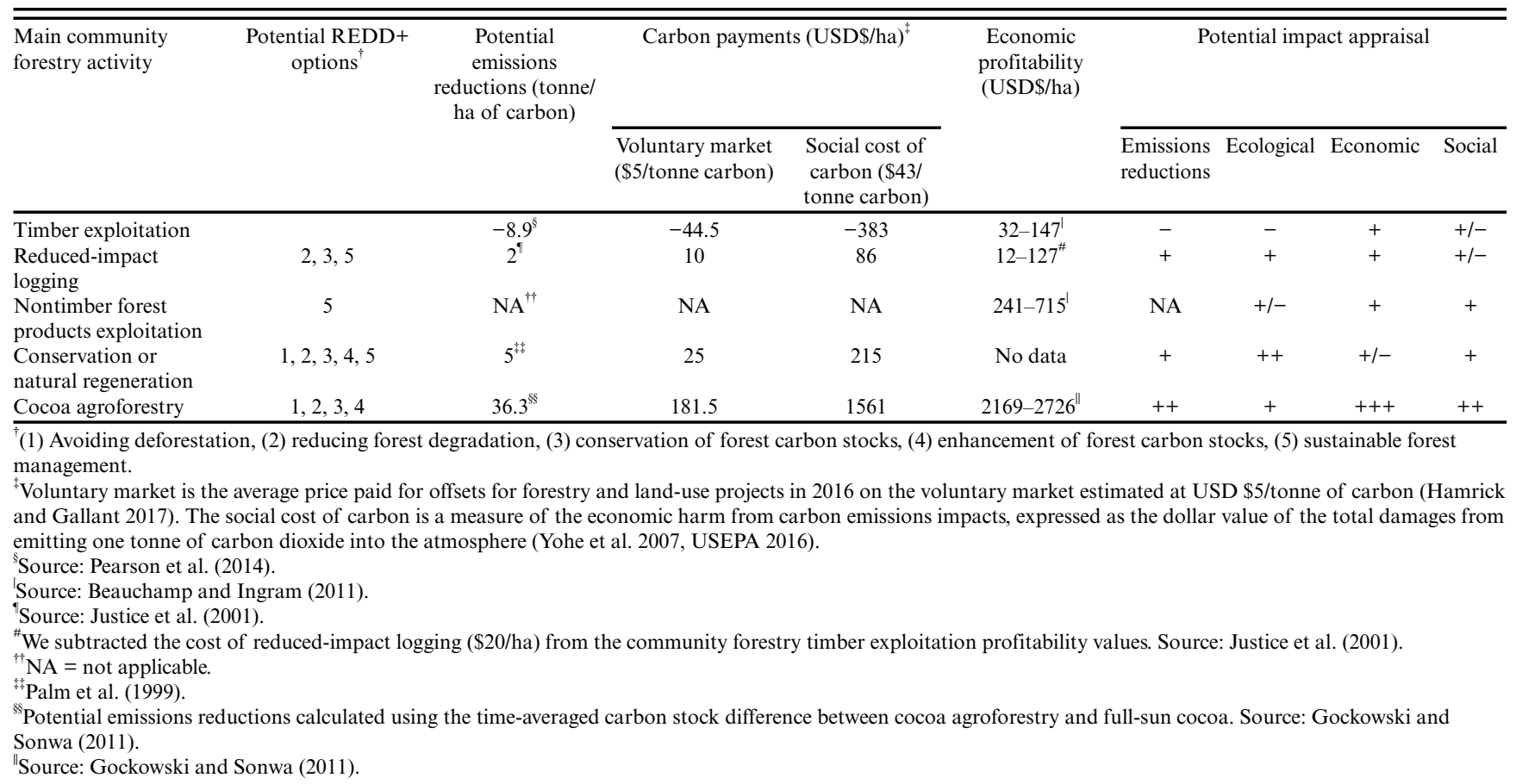

\section{Timber exploitation}

Logging is practiced in $\geq 90 \%$ of CFs in Cameroon, but the scale varies, with a few engaged in licensed logging. Timber exploitation in CFs is currently traditional selective logging using portable mills. This practice is largely incompatible with REDD+ objectives because it contributes to forest degradation in CFs and leads to carbon emissions and depletion of carbon stocks. Although the ecological effects of timber exploitation are negative, economic profitability is positive for communities. Using the case studies of the GIC Doh and COVIMOF CFs, located in the East and Centre regions, respectively, Beauchamp and Ingram (2011) show that the economic profitability of timber exploitation in CFs can vary from $\$ 32 /$ ha to $\$ 147 /$ ha $(\sim 18,083$ to 82,283 CFA francs/ha) in these two CFs. From a social perspective, the benefits of timber exploitation for the communities can differ greatly according to whether there is an external company harvesting, and therefore, excluding communities from most key management decisions and co-opting most of the benefits or if the community is self-organized and implements timber exploitation (Cuny et al. 2007).

\section{Reduced-impact logging}

RIL involves practices such as forest mapping, careful planning and building of roads and skid trails, climber cutting, directional felling, minimal use of bulldozers, and avoiding logging in the proximity of rivers and on steep slopes (Justice et al. 2001). RIL, applied together with better planning, organization, and supervision in the forest during operations, represents an opportunity for contributing to reducing emissions from forest degradation, conserving forest carbon stocks, and contributing to sustainable forest management. Thus far, RIL has been only piloted, but, according to Justice et al. (2001), its use in Central Africa would save $2 \mathrm{Mg} / \mathrm{ha}$ of carbon. A study of the feasibility of RIL in Cameroon also showed that after skidding, part of the vegetation had survived on $47 \%$ of the trail length compared to $29 \%$ after conventional logging (Jonkers 2000). These parts of the trail network are likely to recover more rapidly than other sections because some vegetation remains and because the soil has been less compacted (Jonkers 2000). Therefore, RIL has positive carbon sequestration and ecological effects. However, the design and implementation of RIL would cost approximately \$20/ha in Central Africa (Justice et al. 2001), which is often more costly than traditional logging, implying higher financing requirements and potential revenue loss for communities. At the current low carbon market prices of $\sim \$ 5 / \mathrm{Mg}$ of carbon, RIL cannot compete with traditional logging, but could compete if a social cost of carbon of $\$ 43$ was paid or with more stringent market scrutiny with regard to certification if a higher premium price is to be sought. From a social perspective, the benefits of RIL also depend on whether an external company harvests or if the community is self-organized and implements timber exploitation (Cuny et al. 2007).

\section{Nontimber forest product exploitation}

The collection of NTFPs such as njangsa (Ricinodendron heudelotii), bitter kola (Garcinia kola), bush mango (Irvingia gabonensis), moabi oil (Baillonella toxisperma), rattan, and other products is highly prevalent in CFs in Cameroon. There is relatively little evidence suggesting that NTFP harvesting affects carbon stocks, but there is some evidence of negative effects of 
poor harvesting techniques and overharvesting of tree bark and rattan for tree survival and maintenance of forest structure (Nkeng et al. 2010). Therefore, a balance must be struck between resource sustainability and benefits of exploitation. Nevertheless, the ecological effects of NTFP exploitation would be minimal compared to those from logging. Beauchamp and Ingram (2011) showed that the economic profitability of NTFP exploitation is generally substantive, varying from $\$ 241 /$ ha to $\$ 715 /$ ha $(\sim 135,605$ to $402,315 \mathrm{CFA}$ francs/ha), which yields much better income than current carbon payments that could occur with RIL or conservation or natural regeneration. However, although NTFP exploitation is common for subsistence, there are currently few enterprises that support value-added NTFP exploitation in CFs in Cameroon for commercial purposes.

\section{Conservation or natural regeneration}

CFs are located in the nonforest permanent zones and often have been depleted; therefore, they are secondary forests. Conserving such secondary forests and allowing natural regeneration features are part of several CF SMPs. Natural regeneration can enhance carbon stocks by up to $5 \mathrm{Mg} / \mathrm{ha}$ of carbon (Palm et al. 1999). Given the enormous species recovery in the process of regeneration, the ecological effects of this option are also largely positive (Gockowski and Sonwa 2008). From an economic perspective, there are trade-offs to consider. Conservation or natural regeneration of fallows and degraded areas in CFs often require sacrificing sizeable portions of land in the $\mathrm{CF}$ and foregoing livelihood activities in those areas. This restriction translates into losses of income and material benefits to communities, and current low carbon market prices of $\sim \$ 5 / \mathrm{Mg}$ of carbon are unlikely to compete with other more economically profitable activities. Hence, commensurate REDD+, e.g., at a social cost of carbon of $\$ 43$, or biodiversity payments would be needed to compensate. Assisted natural regeneration, wherein NTFP species are introduced, could also be a viable option for enhancing the economic viability of such areas because they could subsequently serve as NTFP collection areas. The corresponding social benefits could also be increased given the extensive involvement of women in NTFP collection. Potential ecotourism opportunities could also add economic value.

\section{Cocoa agroforestry systems}

Cocoa growing is the most widely practiced agricultural activity in southern Cameroon and is largely responsible for most deforestation. It is therefore an important practice within CFs and adjacent areas. Many deforested or highly degraded CF areas already include village agricultural lands with cocoa as a dominant cash crop. Hence, their management is critical because adopting cocoa agroforestry systems has the potential to avoid further deforestation, reduce forest degradation, conserve forest carbon stocks, and enhance forest carbon stocks by supplying important sources of timber for fuelwood, construction wood, and farm tools that would otherwise be sourced from adjacent or distant forests (Alemagi et al. 2015). Using the time-averaged carbon stock difference between cocoa agroforestry systems and full-sun cocoa, the emissions reduction potential of cocoa agroforestry is estimated at $36.3 \mathrm{Mg} / \mathrm{ha}$ of carbon (Gockowski and Sonwa 2011). Ecologically, aside from the shade-, fruit-, and timber trees that are grown, cocoa agroforestry systems can reduce soil erosion and provide organic input to the soil through leaf litter (Gockowski and Sonwa 2008). In addition, intensified cocoa agroforestry systems with various timber and fruit-producing tree species can increase productivity and diversify the farmer's income streams on the same piece of land, resulting in an increase in income and a reduction in the demand for land, thereby sparing the forest (Alemagi et al. 2015). Gockowski and Sonwa (2011) show that the economic profitability of cocoa agroforestry (from direct marketization) is generally substantive, varying from $\$ 2,169 /$ ha to $\$ 2,726 /$ ha $(\sim 1,223,222$ to $1,537,426 \mathrm{CFA}$ francs/ha) under different price policy regimes. However, cocoa agroforestry in many instances entails cocoa productivity trade-offs and, therefore, potentially reduced incomes from cocoa (Minang et al. 2014). Compared to full-sun cocoa, cocoa agroforestry may produce slightly less, i.e., between $15 \%$ and $25 \%$ less (Gockowski and Sonwa 2011). Choosing a cocoa agroforestry approach in deforested or highly degraded CF areas for its compatibility with REDD+ and higher biodiversity benefits needs careful management of trees and tree products that can compensate for any potential cocoa income loss. Socially, with the increase in the supply of wood and nonwood products on the cocoa farm, less time, effort, and cost are required for harvesting forest products (Alemagi et al. 2015). Cocoa agroforestry in deforested or highly degraded $\mathrm{CF}$ areas is currently the most economically competitive option for implementing REDD+ and is the only option to have a significant emissions reduction potential while delivering ecological, economic, and social cobenefits.

\section{HOW CAN COMMUNITY FORESTRY ARCHITECTURE IN CAMEROON ENABLE OR INHIBIT REDD+?}

Understanding the potentially enhancing and inhibiting features of $\mathrm{CF}$ architecture in Cameroon is critical to achieving REDD+ implementation. We next expand on both of these festures.

\section{Potentially enhancing features of community forest architecture for REDD+ implementation}

\section{Legal and institutional community forest frameworks and} practices compatible with REDD+ safeguards

In comparison with other forest management units, CFs have better legislation and institutional frameworks (Minang et al. 2007), which are advantages in supporting REDD+. The way that CF development was framed by the 1994 Cameroon forestry law 94/01 and its decree 95/531 of implementation makes CFs consistent with national forests programs, as requested by one of the REDD+ safeguards. In addition to the laws and institutional framework, certain practices around the establishment and management of CFs show tremendous compatibility with REDD+ safeguards. The introduction of the environmental impact notice in May 2005, which is the main tool to ensure that activities proposed in CFs do not result in negative environmental outcomes, as well as the development and adoption of certification standards for CF initiatives in 2010, are consistent with the REDD+ safeguard regarding conservation of natural forest and biological diversity. Another point is that CF legal entities constituted at the local level have relied on a participatory approach involving stakeholders in decision making throughout the planning of $\mathrm{CF}$ establishment. This process includes sensitization of the community involved, participatory field work with the villages, and various consultation meetings to inform and seek the agreement of surrounding villages (Movuh 2013). This widespread participation in processes for creation and implementation of CFs is compatible with the REDD+ 
safeguards on the respect for the knowledge and rights of indigenous people and local communities as well as the full and effective participation of relevant stakeholders in REDD+ actions.

\section{Experience with and knowledge of related pilot schemes}

The community forest subsector has benefited from and experienced REDD+-like pilot projects that could prove vital for developing REDD+. Two main project experiences are related here: (1) a pioneering community payment for ecosystem services (C-PES) project, launched in 2009 for 3.5 years in the Nkolenyeng and Nomedjoh CFs in the South and East regions, respectively, and coordinated by the Centre pour l'Environnement et le Développement; and (2) a performance-based finance project called Dryad funded by the British Department for International Development and operated by the World Agroforestry Centre since 2015 in the Littoral, South, Centre, East, and South West regions. The C-PES project explored how to develop the potential for CFs through REDD+ (Awono et al. 2014). Its primary goal was to maintain and enhance existing forest cover and carbon stocks in each community and use the finance generated from the sale of carbon credits to improve livelihoods in each community (Plan Vivo 2012). Key findings from this project were that payments for ecosystem services in combination with REDD+ approaches can be useful catalysts for improving community control over forests and forest resources, local institutions, and livelihood opportunities, but that they involve working within existing community, political, and institutional constraints to bring about change (Harley 2012). They also require a fundamental consideration of equity dimensions and an emphasis on institutional and capacity development (Harley 2012). Harley (2012) also highlights that, although effective project development may be costly and carbon abatement values high in the short term, effective carbon abatement values decrease significantly over the longer term. However, the initial level of investment can vary significantly because communities have different histories, economies, and experiences of development and forest management (Harley 2012). The Dryad project uses a performance-based financing approach to diversified, viable, and sustainable $\mathrm{CF}$ enterprises against a number of agreed social, economic, and environmental indicators and is conditioned on success. Experience from the World Agroforestry Centre on monitoring environmental changes, including enrichment planting, forest clearance for economic or noneconomic use, illegal or legal timber harvesting, NTFP collection, and forest cover changes, is therefore very valuable for achieving REDD+ within CFs. Lessons from these projects and others can feed the design and implementation of REDD+ within CFs.

\section{Social capital}

The Community Forestry Network, which was created by the Community Forestry Development Project in 1997 and initially housed within the Forest Department, was set up to enable the exchange of experiences within the scope of the 1994 forest law (Mandondo 2003). The objectives of the Community Forestry Network are as follows: lobbying for appropriate implementation of the community forestry law and its implementation instruments, collection and dissemination of information on community forestry and natural resource management, capacity building of the network and other stakeholders, and effective and efficient functioning of the network (Mandondo 2003). Over the years, the Community Forestry Network has played a central role in the establishment of CFs in Cameroon and has contributed tremendously to legal and institutional reforms (Minang et al. 2017) by influencing environmental policy change as well as partnering with government in the implementation of such policy. This network, in effect, is a community of practice with common values and recognition of the need to work together. Even at the regional level, there have been some collaboration between multiple CFs, especially in the East region, with the creation of CF cooperatives, e.g., Cooperative Agroforestiere de la Trinational (Minang et al. 2017).

\section{Potentially inhibiting features of community forest architecture for REDD+ implementation}

Elite capture and corruption

Scholars reveal that local CF legal entities are often led by influential actors such as village elites, local chiefs, and village elders, or by urban elites with family connections to the village, who can finance or facilitate the processes and therefore align participation to their interests (Etoungou 2003, Oyono 2004a). There is also underrepresentation of women and vulnerable community members in CF legal entities (Etoungou 2003, Oyono 2004a). In the Mt. Cameroon region, inequitable relationships between indigenous people and migrants over forest resources have been reported in which indigenous people are comparatively overrepresented in decision making for the $\mathrm{CF}$, whereas nonindigenous people are underrepresented (Nuesiri 2008). Misappropriation of funds (e.g., co-option of benefits by the forestry service and private logging companies), poor transparency and accountability, and generalized conflicts about control of forest resources are recurrent issues in Cameroon, and CFs are no exception (Oyono et al. 2006, Ezzine de Blas et al. 2011, Javelle 2012). In addition, overlap between traditional management institutions and new legal entities created for CFs is also a recurrent source of conflict (Ezzine de Blas et al. 2009).

Financing and technical challenges

Implementing REDD+ activities will require additional investments, which is likely to aggravate an already financially constrained environment within CFs. Indeed, CFs in Cameroon experience very difficult financing challenges, starting with the issue of fulfilling the financial demands of the required $\mathrm{CF}$ planning processes. The costs and technical skills needed to establish a SMP and conduct an inventory of forest resources remain out of reach for most communities (Harley 2012), with costs potentially ranging from $\$ 12,000$ to $\$ 24,000$ (Mbile et al. 2009). Therefore, in the absence of international funds to support the development of SMPs, communities are giving exploitation rights to logging companies and service providers, which excludes the communities from direct involvement in management and lowers their bargaining power and potential to benefit from CFs (Oyono 2004b). Even though the Ministry of Forestry and Wildlife issues 2-year provisional management agreements since 2009, allowing communities to exploit the forest during the initial two years and helping them to receive revenues that permit the elaboration of the required management plan (Eyebe et al. 2011), it is often not sufficient, and CFs would require much more financing until they become established as small forest enterprises (Eyebe et al. 2011). In addition to the shortage of finance, CFs also face a number of regulatory barriers that limit enterprise 
operations and market access (Mbile et al. 2009) as well as a deficient access to credit (Tomaselli and Hajjar 2011).

\section{Uncertainty about user and carbon rights}

The management agreement signed between communities and the forest administration allows communities to manage and use areas of nonpermanent forest land for 25 years on a renewable basis. This agreement remains a kind of "lease agreement" whereby the land is communally leased and, if not renewed, the land reverts back to government control (MINEF 1998). The Minister also reserves the right to terminate the management contract with communities and, therefore, withdraw rights of use in cases in which communities do not respect the management agreement (Minang et al. 2007). This situation happened in 2004 2005, when there was a suspension of many CFs by the MINEF for "bad management". The fact that communities only have forest user rights, as opposed to secure, enforceable, and nondiscretionary forest tenure rights, remains an issue for CFs and REDD+ because communities do not have a sense of security in their rights. Carbon rights come as an addition to the already complex layers of unresolved property rights. Communities hold exclusive rights to $\mathrm{CF}$ products, but there is uncertainty about whether carbon can be considered a forest product. Section 9(1-2) of the 1994 Forestry law defines forest products as comprising:

\begin{abstract}
... mainly wood and non-wood products as well as wildlife and fishery resources derived from the forest. Certain forest products such as ebony, ivory, wild animal horns, as well as certain animal, plant and medicinal species or those, which are of interest, shall be classified as special. The list of special products shall be fixed, as and when necessary, by the competent ministry.
\end{abstract}

Therefore, regulatory uncertainty about carbon rights, and therefore earnings, could be a problem for REDD+ implementation.

\section{HOW CAN SYNERGIES BE ENABLED BETWEEN COMMUNIT FORESTRY AND REDD+ IN CAMEROON?}

We next suggest and discuss various strategies and ways forward to enable REDD+ in CFs in Cameroon.

\section{Clarify carbon rights, making use of ongoing forestry law reforms}

One of the new proposals in the current forestry law reform that provides a step in the right direction is the stipulation that all trees planted by an individual on private forest or land without an official land title should be the property of that individual and not the state (Minang et al. 2008). Such reforms should also address carbon ownership or, as a minimum, the right for communities to have a share of the benefits linked to carbon achievements (Minang et al. 2008, Gilmour 2016). This reform would reduce risks of REDD+ project failures in CFs and would promote a transparent and equitable system (Minang et al. 2007). In the absence of such clarification about carbon rights, negotiated transparent arrangements might still be agreed upon with the Cameroonian government.

\section{Develop a benefit-sharing mechanism for REDD+ in community forests across scales}

There is currently no existing benefit-sharing mechanism across scales in Cameroon either for REDD+ or CFs. In REDD+, the money is supposed to flow from international or industry sources to national governments (Gilmour 2016), and there are fears that carbon forestry could motivate a partial recentralization of forest management rights (Phelps et al. 2010). Therefore, if CFs are to deliver REDD+, an equitable, effective, and efficient benefitsharing mechanism from the national to the local level is required, with clear rules for rewarding emissions reductions in CFs. Practical and concrete rules about who will be considered eligible for payments, for what, and how much communities may expect to get, are critical (Skutsch 2013). There have been only a few examples in the literature in which prototype REDD+ projects have been set up in community-based managed forests and the distribution of benefits tested. In the C-PES project in the Nkolenyeng and Nomedjoh CFs, the project delivered $>80 \%$ of its funds directly to the communities. A CF management group oversees the distribution of benefits to community activity groups, who implement activities, and to social benefit groups composed of vulnerable community members (e.g., elderly), who receive special consideration and support (Harley 2012). One innovation of this project is the creation of community bank accounts, which have proved to be more transparent than cash payments, which are rarely traceable (Harley 2015). The C-PES project also introduced transparent accounting systems that oblige the legal entity for each CF to share financial management information with community members and to establish a trust committee to oversee the operation of the C-PES mechanisms and management and distribution of revenues (Harley et al. 2012).

In terms of testing benefit distribution, a project operating in three watersheds in Nepal calculated benefits to each community based on weighting of carbon achievements and a range of social criteria (poor groups, indigenous people, and women, aiming to prevent elite capture of benefits) and on a fixed total amount available for carbon payments within the project (Balderas Torres and Skutsch 2015). In Vietnam, the Programme for Forest Environmental Services is using an index called the $\mathrm{K}$ coefficient, which is based on forest status, type, and difficulty of management, to benefit mostly the poor; Vietnam is developing a similar index called the R-factor for REDD+ payments (Balderas Torres and Skutsch 2012, Hoang et al. 2013). These systems are variations of the standard payment-for-performance model that Cameroon could consider while designing its benefitsharing mechanism for REDD+ in CFs to capture social aspects. Several governance issues of accountability, equity, fairness, and transparency partly observed in the Cameroonian land-rent fee program and highlighted by the C-PES project review and the ongoing Dryad performance-based finance project in CFs need to be avoided (Harley et al. 2012, Assembe-Mvondo et al. 2013, Harley 2015, Minang et al. 2017, Piabuo et al. 2018). Specific attention might also be needed with respect to the attribution of emission reductions in the REDD+ benefit-sharing mechanism in the case of CFs, following experiences elsewhere (Skutsch and Solis 2011, Balderas Torres and Skutsch 2012).

\section{Build monitoring, reporting, and verification infrastructure for REDD+ in community forests}

At the national level, CFs have neither a specific guide for monitoring performance in terms of sustainable forest management nor historical data on biomass and carbon density changes over time that would allow the establishment of a reliable 
baseline or reference scenario for REDD+ (Skutsch and Solis 2011). However, Minang et al. (2008) emphasize that there could be underrecognized data in CF project areas that could facilitate baseline and carbon additionality analyses. They cite the case of the Mt. Cameroon catchment area, which has a database consisting of georeferenced forest inventory data with 20,000 records from approximately 300 forest samples, and which could be modified using additional field information and regression equations to serve carbon management purposes (Minang et al. 2008).

At the local level, the C-PES project demonstrated that community field workers who are properly trained and coordinated well can carry out accurate mapping of land-use and land-cover change as well as provide qualitative information on the drivers and agents of deforestation. The C-PES monitoring cost was estimated to be $\$ 59.2 / \mathrm{km}^{2}$, which lies at the lower end of the $\$ 0.5 / \mathrm{km}^{2}$ to $\$ 550 / \mathrm{km}^{2}$ range of monitoring costs given by Böttcher et al. (2009) following an assessment of different monitoring techniques and REDD+ monitoring requirements and costs (McGhee 2015). It is therefore important to invest and create local capacities if communities are to do more autonomous monitoring. The question of monitoring, reporting, and verification costs needs to be addressed. Although participatory monitoring, reporting, and verification is one pathway that could make the process more efficient (Skutsch 2005, Zahabu 2006, McGhee 2015), upfront capacity-building investment by government will be necessary.

\section{Invest in local community capacity development}

Investing in capacity development for local community legal entities, and empowering them with negotiation skills, is a prerequisite to ensure legitimate, effective, efficient, and equitable REDD+ delivery in CFs (Akoa Akoa 2007). CF community members need to be trained, with increased literacy capacity to start, technical skills (forest management, use, and planning; monitoring, reporting, and verification), enterprise development skills (financial management and bookkeeping, forest enterprise development), and capacities for good governance and leadership. Capacity building of skills and access to leadership roles will enable communities to have sufficient authority, information, and support to take a more active role in the development of the SMP, determine whether they want to engage with REDD+, and negotiate revenue sharing. There is also need to increase the capacity of government and other partners to support community-level management institutions.

\section{Promote an integrated approach to community forest management}

As demonstrated in the preceding sections, the enhancing and inhibiting factors, as well as the enabling conditions, are vastly interdependent and connected; hence, moving toward a holistic approach to CF management is imperative (Duguma et al. 2018). Approaching CF management from a multiobjective and multipurpose perspective wherein climate mitigation (REDD+) and adaptation (ecosystem-based adaptation) are addressed alongside the original livelihood and forest management objectives of CF could be highly rewarding. Options for REDD+ within community forestry in Cameroon (Table 2) show that RIL, conservation, and agroforestry also generate significant economic, social, and ecological benefits. These options could justify the use of both adaptation and mitigation finance to unlock the financing challenges for CFs. Innovative landscapelevel financing and technical and capacity support could also be leveraged within the context of sustainable development goals (Bernard et al. 2018) or landscape restoration finance and institutional support. This shift in perspective will seek to engage multiple sectors beyond forestry (e.g., finance, private sector, commerce) in CF management in ways that will enable achieving climate, economic, social, and ecological objectives simultaneously.

\section{CONCLUSION}

We aimed to explore the extent to which CFs can achieve REDD+ objectives in Cameroon. Our aim is premised on the fact that while community forestry features as a key component for achieving REDD+ in Cameroon, little has been done to understand what options exist and the extent to which the current architecture of community forestry can accommodate or coexist with REDD+ in an effective and efficient manner. We explored this idea by seeking answers to three main questions: (1) What are the options through which CFs can contribute to REDD+, and how feasible are they? (2) How can the current CF architecture potentially enhance or inhibit REDD+ implementation? (3) How can synergies be enabled between CF and REDD+? We reviewed publications on REDD+ and community forestry, including primarily peer reviewed literature, reports, laws, and policy documents, as well as elicit expert knowledge, to analyze and interpret our findings.

With regard to options for achieving REDD+ within CFs, cocoa agroforestry in deforested or highly degraded CFs is currently the most competitive option for implementing REDD+ while delivering ecological, economic, and social cobenefits. However, cocoa agroforestry will require careful management of trees and tree products that can compensate for any potential cocoa income loss. RIL, which has only been piloted so far, and conservation or natural regeneration are technically sound options for emissions reductions within CFs in Cameroon, but they are unlikely to compete with other more profitable activities at current low carbon market prices of approximately USD \$5/tonne of carbon. Depending on the context, assisted natural regeneration with introduction of NTFP species, potential ecotourism opportunities, or a higher premium price for RIL could be viable options for enhancing economic return and achieving REDD+. Furthermore, if a social cost of carbon of \$43/tonne of carbon was paid, then REDD+ might become more competitive. This is unlikely, however, given prevailing market conditions. There is little evidence about how NTFP exploitation affects carbon stocks, but NTFP could potentially have a better economic and social impact for communities compared to timber exploitation and RIL, as well as a minimized ecological impact. However, more development of innovative enterprises for NTFP exploitation for commercial purposes is critical to achieve the potential of this activity (Minang et al. 2019).

If REDD+ is implemented in CFs, a revision of the SMP should incorporate those activities that can be beneficial to REDD+ and balance them with other profitable activities such as timber and NTFP extraction. A CF cannot be overly reliant on REDD+ carbon payments but should promote diversification of the community's forest-based income source that increases the resilience of the $\mathrm{CF}$. Given the current low carbon market prices, 
REDD+ carbon payments can only be envisaged currently as an additional benefit for a $\mathrm{CF}$.

With regard to the extent to which the current $\mathrm{CF}$ architecture can accommodate REDD+, a set of factors could potentially favor REDD+ implementation. These factors include good legal and institutional frameworks, practices compatible with REDD+ safeguards, experience and knowledge in related C-PES and performance-based finance pilots, and social capital in a community of practice. Current $\mathrm{CF}$ architecture also features potentially inhibiting factors for REDD+ such as poor governance (notably, elite capture and corruption), unclear carbon rights, and financing and technical challenges.

To enable CFs to serve REDD+ objectives, we identify a set of enabling actions for delivery of REDD+ within CFs in Cameroon. These enabling actions are: clarifying carbon rights, and establishing a benefit-sharing mechanism from the national to the local level, with clear rules for rewarding emissions reductions in CFs and investing in community capacity-building in technical, enterprise development, governance, and leadership aspects. More importantly, adopting an integrated approach in which CFs serve multiple objectives, including ecosystem-based adaptation, REDD+ and the original community forestry objectives could enable drawing from adaptation and mitigation finance and technical support, and provide long-term sustainable development benefits.

Responses to this article can be read online at: http://www.ecologyandsociety.org/issues/responses. $\mathrm{php} / 10708$

\begin{abstract}
Acknowledgments:
We acknowledge the financial support of the Department for International Development through the DRYAD project, "Financing sustainable community forest enterprises in Cameroon," which supported the development of this paper.
\end{abstract}

\section{LITERATURE CITED}

Agrawal, A., and A. Angelsen. 2009. Using community forest management to achieve REDD+ goals. Pages 201-211 in A. Angelsen, M. Brockhaus, M. Kanninen, E. Sills, W. D. Sunderlin, and S. Wertz-Kanounnikoff, editors. Realising REDD+: national strategy and policy options. Center for International Forestry Research, Bogor, Indonesia. [online] URL: https://www.cifor.org/ publications/pdf files/Books/BAngelsen0902.pdf

Agrawal, A., A. Chhatre, and R. Hardin. 2008. Changing governance of the world's forests. Science 320(5882):1460-1462. http://dx.doi.org/10.1126/science.1155369

Akoa Akoa, R. Jr. 2007. Economic analysis of community forest projects in Cameroon. Thesis. Georg-August University of Goettingen, Goettingen, Germany. [online] URL: https:// agritrop.cirad.fr/550164/1/document 550164.pdf

Alemagi, D. 2010. A comparative assessment of community forest models in Cameroon and British Columbia, Canada. Land Use Policy 27(3):928-936. https://doi.org/10.1016/j.landusepol.2009.12.006
Alemagi, D., L. Duguma, P. A. Minang, F. Nkeumoe, M. Feudjio, and Z. Tchoundjeu. 2015. Intensification of cocoa agroforestry systems as a REDD+ strategy in Cameroon: hurdles, motivations, and challenges. International Journal of Agricultural Sustainability 13(3):187-203. http://dx.doi.org/10.1080/14735903.2014.940705

Alemagi, D., P. A. Minang, M. Feudjio, and L. Duguma. 2014. REDD+ readiness process in Cameroon: an analysis of multistakeholder perspectives. Climate Policy 14(6):709-733. http://dx. doi.org/10.1080/14693062.2014.905439

Amungwa, F. A. 2011. The evolution of conflicts related to natural resource management in Cameroon. Journal of Human Ecology 35(1):53-60. https://doi.org/10.1080/09709274.2011.11906390

Arnolds, J. E. M. 2001. Forests and people: 25 years of community forestry. Food and Agriculture Organization, Rome, Italy. [online] URL: http://www.fao.org/docrep/012/y2661e/y2661e00.htm

Assembe-Mvondo, S., M. Brockhaus, and G. Lescuyer. 2013. Assessment of the effectiveness, efficiency and equity of benefitsharing schemes under large-scale agriculture: lessons from land fees in Cameroon. European Journal of Development Research 25 (4):641-656. https://doi.org/10.1057/ejdr.2013.27

Awono, A., E. Barreau, and H. Owona. 2014. Community payments for ecosystem services in the south and east regions of Cameroon. Pages 203-217 in E. O. Sills, S. S. Atmadja, C. de Sassi, A. E. Duchelle, D. L. Kweka, I. A. P. Resosudarmo, and W. D. Sunderlin, editors. REDD+ on the ground: a case book of subnational initiatives across the globe. Center for International Forestry Research, Bogor, Indonesia. [online] URL: http://www. cifor.org/library/5271/community-payments-for-ecosystem-servicesin-the-south-and-east-regions-of-cameroon/

Balderas Torres, A., and M. Skutsch. 2012. Splitting the difference: a proposal for benefit sharing in reduced emissions from deforestation and forest degradation (REDD+). Forests 3 (1):137-154. http://dx.doi.org/10.3390/f3010137

Balderas Torres, A., and M. Skutsch. 2015. Special issue: The potential role for community monitoring in MRV and in benefit sharing in REDD+. Forests 6(1):244-251. http://dx.doi. org/10.3390/f6010244

Beauchamp, E., and V. Ingram. 2011. Impacts of community forests on livelihoods in Cameroon: lessons from two case studies. International Forestry Review 13(4):389-403. https://doi. org/10.1505/146554811798811371

Bernard, F., S. Chesterman, C. L. Neely, R. Ramos Delgado, V. Robiglio, G. Gauldra, and M. van Noordwijk. 2018. Review of policy frameworks for effective REDD+ implementation in the context of the sustainable development goals and other national action plans. World Agroforestry Centre, Nairobi, Kenya.

Bluffstone, R. 2013. Economics of REDD+ and community forestry. Journal of Forest and Livelihood 11(2):69-74. http://dx. doi.org/10.3126/jfl.v11i2.8624

Böttcher, H., K. Eisbrenner, S. Fritz, G. Kindermann, F. Kraxner, I. McCallum, and M. Obersteiner. 2009. An assessment of monitoring requirements and costs of 'Reduced Emissions from Deforestation and Degradation'. Carbon Balance and Management 4(1):7. https://doi.org/10.1186/1750-0680-4-7 
Brown, D., and K. Schreckenberg. 2001. Community forestry: facing up to the challenge in Cameroon. Rural Development Forestry Network Paper 25a. Overseas Development Institute, London, UK. [online] URL: https://www.odi.org/sites/odi.org. $\underline{\text { uk/files/odi-assets/publications-opinion-files/1206.pdf }}$

Cameroon Ministry of Forests and Fauna (MINFOF). 2009. Manual of procedures for the attribution, and norms for the management, of community forests. MINFOF, Yaoundé, Cameroon.

Cameroon Ministry of the Environment and Forestry (MINEF). 1998. Manual of procedures for the attribution, and norms for the management, of community forests. MINEF, Yaoundé, Cameroon.

Chhatre, A., and A. Agrawal. 2009. Trade-offs and synergies between carbon storage and livelihood benefits from forest commons. Proceedings of the National Academy of Sciences 106 (42):17667-17670. http://dx.doi.org/10.1073/pnas.0905308106

Cuny, P., A. A. Ango, Z. A. Ondoa. 2007. Local and decentralized forest management in Cameroon: the case of the Kongo community forest. In R. Oberndorf, P. Durst, S. Mahanty, K. Burslem, and R. Suzuki, editors. A cut for the poor: proceedings of the International Conference on Managing Forests for Poverty Reduction: capturing opportunities in forest harvesting and wood processing for the benefit of the poor. Food and Agriculture Organization, Rome, Italy. [online] URL: http://www.fao.org/ docrep/010/ag131e/ag131e09.htm

Duguma, L. A., P. A. Minang, D. Foundjem-Tita, P. Makui, and S. M. Piabuo. 2018. Prioritizing enablers for effective community forestry in Cameroon. Ecology and Society 23(3):1. https://doi. org/10.5751/ES-10242-230301

Egbe, E. S. 2001. The concept of community forestry under Cameroonian law. Journal of African Law 45(1):25-50. https:// www.jstor.org/stable/3558967

Etoungou, P. 2003. Decentralization viewed from inside: the implementation of community forests in East Cameroon. Environmental Governance in Africa Series Working Paper 12. World Resources Institute, Washington, D.C., USA. [online] URL: http://www.wri.org/sites/default/files/eaa etoungou.pdf

Eyebe, A., D. Endamana, J. Sayer, M. R. Perez, A. K. Boedhihartono, G. Walters, K. A. Angu, and L. Ngono. 2011. Community forestry and the challenge of aligning with Cameroon's green economy. Nature and Faune 26(1):49-53. [online] URL: http://www.fao.org/docrep/015/an170e/an170e00. pdf

Ezzine de Blas, D., M. R. Pérez, J. A. Sayer, G. Lescuyer, R. Nasi, and A. Karsenty. 2009. External influences on and conditions for community logging management in Cameroon. World Development 37(2):445-456. https://doi.org/10.1016/j. worlddev.2008.03.011

Ezzine de Blas, D., M. Ruiz-Pérez, and C. Vermeulen. 2011. Management conflicts in Cameroonian community forests. Ecology and Society 16(1):8. [online] URL: http://www. ecologyandsociety.org/vol16/iss1/art8/

Fobissie, B. K., E. P. Essomba, N. Sonne, S. N. Ndobé, and V. Retana. 2012. Social safeguards and the rights of indigenous peoples in the REDD+ process of Cameroon: lessons from experiences in natural resources management. Worldwide Fund for Nature in Partnership with the Centre for Environment and Development, Yaoundé, Cameroon.

Gilmour, D. 2016. Forty years of community-based forestry: a review of its extent and effectiveness. FAO Forestry Paper 176. Food and Agriculture Organization, Rome, Italy. [online] URL: http://www.fao.org/3/a-i5415e.pdf

Gockowski, J., and D. Sonwa. 2008. Biodiversity and smallholder cocoa production systems in West Africa. Sustainable Tree Crops Program, Interntional Institute of Tropical Agriculture, Accra, Ghana. [online] URL: http://www.sidalc.net/repdoc/A4776i/ A4776i.pdf

Gockowski, J., and D. Sonwa. 2011. Cocoa intensification scenarios and their predicted impact on $\mathrm{CO}_{2}$ emissions, biodiversity conservation, and rural livelihoods in the Guinea rain forest of West Africa. Environmental Management 48(2):307-321. https://doi.org/10.1007/s00267-010-9602-3

Hamrick, K., and M. Gallant. 2017. Unlocking potential: state of the voluntary carbon markets 2017. Forest Trends' Ecosystem Marketplace, Washington, D.C., USA. [online] URL: $\underline{\text { https:// }}$ www.forest-trends.org/wp-content/uploads/2017/07/doc 5591.pdf

Harley, R. 2015. Community PES policy brief 1: lessons and opportunities for REDD+. Bioclimate Research and Development, Edinburgh, UK.

Harley, R., M. Riddell, and S. N. Ndobe. 2012. REDD+ beyond carbon: insights from a community payments for ecosystem services project in Cameroon. Project Paper 2. Bioclimate Researchand Development, Edinburgh, UK. [online] URL: http:// theredddesk.org/sites/default/files/resources/pdf/2012/ redd_beyond_carbon_community_pes_paper_2012.pdf

Hoang, M. H., T. H. Do, M. T. Pham, M. van Noordwijk, and P. A. Minang. 2013. Benefit distribution across scales to reduce emissions from deforestation and forest degradation (REDD+) in Vietnam. Land Use Policy 31:48-60. https://doi.org/10.1016/j. landusepol.2011.09.013

Javelle, A.-G. 2012. Rights and wrongs in Cameroon's community forests. Focus on land in Africa, World Resources Institute, London, UK, and Landesa, Seattle, Washington, USA. [online] URL: http://www.focusonland.com/fola/en/countries/briefs-rightsand-wrongs-in-cameroons-community-forests/

Jonkers, W. B. J., editor. 2000. Logging, damage and efficiency: a study on the feasibility of reduced impact logging in Cameroon. Tropenbos-Cameroon Reports 00-3. Tropenbos-Cameroon Programme, Kribi, Cameroon. [online] URL: http://www. tropenbos.org/file.php/128/tcpreport00-3.pdf

Justice, C., D. Wilkie, Q. Zhang, J. Brunner, and C. Donoghue. 2001. Central African forests, carbon and climate change. Climate Research 17(2):229-246. [online] URL: https://www.jstor.org/ stable/24867358

Klein, M., B. Salla, and J. Kok. 2001. Attempts to establish community forests in Lomié, Cameroon. Rural Development Network Paper 25f(ii). Overseas Development Institute, London, UK. [online] URL: https://www.odi.org/sites/odi.org.uk/files/ odi-assets/publications-opinion-files/1226.pdf 
Mandondo, A. 2003. Snapshots views of international community forestry networks: Cameroon country study. Center for International Forestry Research, Yaoundé, Cameroon. [online] URL: http://citeseerx.ist.psu.edu/viewdoc/download? $\underline{\text { doi }=10.1 .1 .513 .8778 \& \mathrm{rep}=\text { rep1\&type }=\mathrm{pdf}}$

Mbile, P., G. Ndzomo-Abanda, H. Essoumba, and A. Misouma. 2009. Alternate tenure and enterprise models in Cameroon: community forests in the context of community rights and forest landscapes. World Agroforestry Centre, Nairobi, Kenya, and Rights and Resources Initiative, Washington, D.C., USA. [online] URL: https://rightsandresources.org/wp-content/exported-pdf/ cameroonenglish.pdf

McGhee, W. 2015. Community PES policy brief 4: efficiency of community PES forest monitoring. Bioclimate Research and Development, Edinburgh, UK.

Minang, P. A., L. A. Duguma, F. Bernard, D. Foundjem-Tita, and Z. Tchoundjeu. 2019. Evolution of community forestry in Cameroon: an innovation ecosystems perspective. Ecology and Society 24(1):1. https://doi.org/10.5751/ES-10573-240101

Minang, P. A., L. A. Duguma, F. Bernard, O. Mertz, and M. van Noordwijk. 2014. Prospects for agroforestry in REDD+ landscapes in Africa. Current Opinion in Environmental Sustainability 6:78-82. https://doi.org/10.1016/j.cosust.2013.10.015

Minang, P. A., L. A. Duguma, S. P. Mandiefe, D. Foundjem, and Z. Tchoundjeu. 2017. Community forestry as a green economy pathway: two decades of learning in Cameroon. ASB Policy Brief 53. ASB Partnership for the Tropical Forest Margins and World Agroforestry Centre, Nairobi, Kenya. [online] URL: http://www. asb.cgiar.org/Publications\%202018/ASB PB53 ENG.pdf

Minang, P. A., M. K. McCall, and H. T. A. Bressers. 2007. Community capacity for implementing Clean Development Mechanism projects within community forests in Cameroon. Environmental Management 39(5):615-630. [online] URL: http:// dx.doi.org/10.1007/s00267-005-0275-2

Minang, P. A., M. K. McCall, M. M. Skutsch, and J. J. Verplanke. 2008. A data support infrastructure for Clean Development Mechanism forestry implementation: an inventory perspective from Cameroon. Mitigation and Adaptation Strategies for Global Change 13(2):157-178. http://dx.doi.org/10.1007/s11027-007-9084-7

Movuh, M. C. Y. 2012. The Colonial heritage and post-Colonial influence, entanglements and implications of the concept of community forestry by the example of Cameroon. Forest Policy and Economics 15:70-77. https://doi.org/10.1016/j.forpol.2011.05.004

Movuh, M. C. Y. 2013. Analyzing the establishment of community forestry $(\mathrm{CF})$ and its processes: examples from the South West region of Cameroon. Journal of Sustainable Development 6(1):76. http://dx.doi.org/10.5539/jsd.v6n1p76

Newton, P., B. Schaap, M. Fournier, M. Cornwall, D. W. Rosenbach, J. DeBoer, J. Whittemore, R. Stock, M. Yoders, G. Brodnig, and A. Agrawal. 2015. Community forest management and REDD+. Forest Policy and Economics 56:27-37. https://doi. org/10.1016/j.forpol.2015.03.008

Ngendakumana, S., E. G. Bachange, P. Van Damme, S. Speelman, D. Foundjem-Tita, Z. Tchoundjeu, A. Kalinganire, and S. B.
Bandiaky. 2013. Rethinking rights and interests of local communities in REDD+ designs: lessons learnt from current forest tenure systems in Cameroon. ISRN Forestry 2013:830902. http://dx.doi.org/10.1155/2013/830902

Nkeng, P. N., V. Ingram, and A. Awono. 2010. Mobilisation et renforcement des capacités des petites et moyennes entreprises impliquées dans les filières des produits forestiers non ligneux en Afrique centrale. Assessment of Prunus africana bark exploitation methods and sustainable exploitation in the South West, NorthWest and Adamaoua regions of Cameroon. Center for International Forestry Research, Yaoundé, Cameroon.

Nuesiri, E. O. 2008. Forest governance challenges on Mount Cameroon. IHDP Update 2. International Human Dimensions Programme on Global Environmental Change. [online] URL: http://www.environmentportal.in/files/Forest.pdf

Oyono, P. R. 2004a. Assessing accountability in Cameroon's local forest management: Are representatives responsive? African Journal of Political Science 9(1):125-136. $\underline{\text { http://dx.doi. }}$ org/10.4314/ajps.v9i1.27363

Oyono, P. R. 2004b. One step forward, two steps back? Paradoxes of natural resources management decentralization in Cameroon. Journal of Modern African Studies 42(1):91-111. https://doi. org/10.1017/S0022278X03004488

Oyono, P. R., J. C. Ribot, and A. M. Larson. 2006. Green and black gold in rural Cameroon: natural resources for local governance, justice and sustainability. Environmental Governance in Africa Working Paper 22. World Resources Institute, Washington, D.C., USA.

Palm, C. A., P. L. Woomer, J. Allegre, L. Arevelo, C. Castilla, D. G. Cordeiro, B. Feigel, K. Hairiah, J. Kotto-Same, A. Mendes, A. Moukam, D. Murdiyarso, R. Njomgang, W. J. Parton, A. Ricse, V. Rodrigues, S. M. Sitompul, and M. van Noorwijk. 1999. Carbon sequestration and trace gas emissions in slash-and-burn and alternative land uses in the humid tropics. Climate Change Working Group Final Report, Phase II. World Agroforestry Centre, Nairobi, Kenya. [online] URL: http://www.worldagroforestry. org/downloads/Publications/PDFS/RP99031.pdf

Pearson, T. R. H., S. Brown, and F. M. Casarim. 2014. Carbon emissions from tropical forest degradation caused by logging. Environmental Research Letters 9(3):034017. https://doi. org/10.1088/1748-9326/9/3/034017

Pelletier, J., N. Gélinas, and M. Skutsch. 2016. The place of community forest management in the REDD+ landscape. Forests 7(8):170. https://doi.org/10.3390/f7080170

Phelps, J., E. L. Webb, and A. Agrawal. 2010. Does REDD+ threaten to recentralize forest governance? Science 328:312-313. http://dx.doi.org/10.1126/science. 1187774

Piabuo, S. M., D. Foundjem-Tita, and P. A. Minang. 2018. Community forest governance in Cameroon: a review. Ecology and Society 23(3):34. https://doi.org/10.5751/ES-10330-230334

Plan Vivo. 2012. Community payments for ecosystem services ( $C$ $P E S)$ in the Congo basin. Bioclimate Research and Development, Edinburgh, UK. [online] URL: http://www.planvivo.org/docs/ PDD-Community-PES-public-comments.pdf 
Readiness Preparation Proposal Team (R-PP Team). 2012. Readiness preparation proposal ( $R-P P)$ : country: Cameroon. Ministère de l'Environnement, de la Protection de la Nature et du Developpement Durable, Yaoundé, Cameroon. [online] URL: http://www.forestcarbonpartnership.org/sites/forestcarbonpartnership. org/

files/Documents/PDF/Oct2012/Cameroon $\% 20$ final $\% 20$ R-PP-EnglishOctober, \%202012.pdf

REDD+ Academy. 2015. Reducing emissions from deforestation and forest degradation. Learning Journal, Edition 1. United Nations-REDD Programme, Geneva, Switzerland. [online] URL: https://www.uncclearn.org/sites/default/files/inventory/ redd academy learning journal eng 0.pdf

Ribot, J. C. 2002. Democratic decentralization of natural resources: institutionalizing popular participation. World Resources Institute, Washington, D.C., USA. [online] URL: https://vtechworks.lib.vt. edu/bitstream/handle/10919/65426/361_ddnr_full_revised.pdf? $\underline{\text { sequence }=1}$

Rights and Resources Initiative. 2015. Who owns the world's land? A global baseline of formally recognized indigenous and community land rights. Rights and Resources Initiative, Washington, D.C., USA. [online] URL: https://rightsandresources.org/wp-content/ uploads/GlobalBaseline web.pdf

Skutsch, M. M. 2005. Reducing carbon transaction costs in community-based forest management. Climate Policy 5 (4):433-443. http://dx.doi.org/10.1080/14693062.2005.9685568

Skutsch, M. 2013. Slicing the REDD+ pie: controversies around the distribution of benefits. CAB Reviews 8(20):1-10.http://dx. doi.org/10.1079/PAVSNNR20138020

Skutsch, M., and M. K. McCall. 2012. The role of community forest management in REDD+. Unasylva 63(239):51-56. [online] URL: https://ris.utwente.nl/ws/portalfiles/portal/6662342

Skutsch, M., and S. Solis. 2011. How much carbon does community forest management save? Pages 16-30 in M. Skutsch, editor. Community forest monitoring for the carbon market: Opportunities under REDD. Earthscan, London, UK.

Tomaselli, M. F., and R. Hajjar. 2011. Promoting community forestry enterprises in national REDD+ strategies: a business approach. Forests 2(1):283-300. https://doi.org/10.3390/f2010283

U.S. Environmental Protection Agency (USEPA). 2016. Social cost of carbon. EPA Fact Sheet. USEPA, Washington, D.C., USA. [online] URL: https://www.epa.gov/sites/production/files/2016-12/ documents/social cost of carbon fact sheet.pdf

United Nations Framework Convention on Climate Change (UNFCCC). 2011. Report of the Conference of the Parties on its sixteenth session, held in Cancun from 29 November to 10 December 2010. Addendum: part two: action taken by the Conference of the Parties at its sixteenth session. FCCC/CP/2010/7/Add.1. United Nations, New York, New York, USA. [online] URL: https:// unfccc.int/resource/docs/2010/cop16/eng/07a01.pdf

United Nations REDD Programme (UN-REDD). 2013. Pondering the role of community forestry in REDD+. UN-REDD Programme, Geneva, Switzerland. [online] URL: https://www. unredd.net/index.php?option $=$ com docman \&Itemid $=134 \& v i e w=$ download\&alias=10987-go-redd-34-role-of-communityforestry-10987\&category slug=go-redd-articles-2548

White, D., and P. A. Minang. 2011. Estimating the opportunity costs of REDD+: a training manual. Version 1.3. World Bank, Washington, D.C., USA. [online] URL: https://www. forestcarbonpartnership.org/redd-opportunity-costs-training-manual

World Resources Institute (WRI). 2014. Cameroon's forest estate. Ministry of Forestry and wildlife. World Resources Institute. [online] URL: http://wriorg.s3.amazonaws.com/s3fs-public/ uploads/CMR Poster 2014 english.pdf

Yohe, G. W., R. D. Lasco, Q. K. Ahmad, N. W. Arnell, S. J. Cohen, C. Hope, A. C. Janetos and R. T. Perez. 2007. Perspectives on climate change and sustainability. Pages 811-841 in M. L. Parry, O. F. Canziani, J. P. Palutikof, P. J. van der Linden, and C. E. Hanson, editors. Climate change 2007: impacts, adaptation and vulnerability. Contribution of Working Group II to the Fourth Assessment Report of the Intergovernmental Panel on Climate Change. Cambridge University Press, Cambridge, UK. [online] URL: https://www.ipcc.ch/site/assets/uploads/2018/03/ ar4 wg2 full report.pdf

Zahabu, E. 2006. Case study 3: Kitulango forest area, Tanzania. Pages 20-25 in D. Murdiyarso and M. Skutsch, editors. Community forest management as a carbon management option: case studies. Centre for International Forestry Research, Bogor, Indonesia. [online] URL: http://www.cifor.org/publications/ pdf_files/Books/BMurdiyarso0602.pdf 